\title{
SERANGAN DAN POPULASI Scotinophara sp. PADA TANAMAN PADI SAWAH DI KABUPATEN BOLAANG MONGONDOW TIMUR
}

\section{ATTACK AND POPULATION OF Scotinophara sp. TO RICE PLANTIN EAST BOLAANG MONGONDOW DISTRICT}

\author{
Alex Hendra Kila1), Ch. L. Salaki²), dan Elisabeth R. M. Meray ${ }^{2)}$ \\ 1)Balai Perlindungan Tanaman Pangan dan Hortikultura Provinsi Sulut \\ 2)Jurusan Hama dan Penyakit Tumbuhan, Fakultas Pertanian Unsrat Manado, 95115
}

\begin{abstract}
The research aimed to find out the attacks and pest populations Scotinophara $s p$. in rice crops have been carried out in EastBolaang Mongondow from July to October 2014. The study used survey methods at several centers of rice cultivation in East Bolaang Mongondow, then set three districts as a test site where sampling. Sampling using Method Diagonal slices then select ten clump of rice plants in each sub-sample plots. Samples were taken at vegetative stage and generative phase. Things were observed in this study is the percentage of infected plants and pest populations. The results showed that the highest percentage of infected rice plants in the age of the plants 8 weeks after plants are found in Sub Tutuyan amounted to 66.66 percent and the lowest sequentially the District Nuangan and the District Kotabunan namely 39.33 percent and 11.13 percent.The highest Scotinophara sp. population density was found based on the location is district Tutuyan 10,11 tail and the lowest sequentially District Nuangan and the District Kotabunan is 1.82 and 0.96 tail. The density of the population by age of the plant, the highest in the plant age 8 mst 12.75 and the lowest sequentially 6,4 and 2 mst is4.38, 0.06 and 0 tail.
\end{abstract}

Keywords : attack, population, Scotinophara sp., rice plant

\section{ABSTRAK}

Penelitian yang bertujuan untuk mengetahui serangandan populasi hama Scotinophara sp. pada tanaman padi sawah telah dilaksanakan di Kabupaten Bolaang Mongondow Timur sejak bulan Juli sampai dengan Oktober 2014. Penelitian menggunakan Metode Survei pada beberapa sentra penanaman padi di Kabupaten Bolaang Mongondow Timur, kemudian menetapkan 3 kecamatan sebagai lokasi penelitian tempat pengambilan sampel. Pengambilan sampel menggunakan Metode Irisan Diagonal dengan memilih sepuluh rumpun tanaman padi pada setiap sub-petak sampel. Pengambilan sampel dilakukan pada fase vegetatif dan fase generatif. Hal-hal yang diamati dalam penelitian ini adalah persentase tanaman terserang dan populasi hama. Hasil penelitian menunjukkan bahwa persentase tanaman padi terserang tertinggi pada umur 8 minggu setelah tanam ditemukan di Kecamatan Tutuyan yaitu 66,66 persen dan terendah secara berurutan Kecamatan Nuangan dan Kecamatan Kotabunan yakni 39,33 persen dan 11,13 persen.Kepadatan populasi Scotinophara sp. tertinggi berdasarkan lokasi dijumpai di Kecamatan Tutuyan yakni 10,11 ekor dan terendah secara berurutan Kecamatan Nuangan dan Kecamatan Kotabunan yakni 1,82 ekor dan 0,96 ekor. Kepadatan populasi berdasarkan umur tanaman, tertinggi pada umur tanaman 8 mst yakni 12,75 ekor dan terendah secara berurutan $6 \mathrm{mst}, 4 \mathrm{mst}$ dan 2 mst yakni 4,38 ekor, 0,06 ekor dan 0 ekor.

Kata kunci :serangan, populasi, Scotinophara sp., tanaman padi 


\section{PENDAHULUAN}

Jenis padi yang banyak dibudidayakan di Kabupaten Bolaang Mongondow Timur adalah varietas serayu, sultan, dan superwin. Semua jenis padi lokal Indonesia harus dilestarikan dan dikembangkan agar terus bermanfaat bagi kehidupan bangsa Indonesia dalam memenuhi kebutuhan hidup maupun kelestarian plasma nutfahnya keberlanjutan. Produktivitas lahan sawah di Indonesia termasuk di Bolaang Mongondow menghadapi berbagai tantangan, diantaranya adalah rendahnya kandungan bahan organik tanah, dan terbatasnya ketersediaan air, terutama pada musim kemarau serta adanya serangan hama dan penyakit tumbuhan (Anonim, 2011; Paendong, dkk., 2011).

Scotinophara sp. merupakan salah satu hama penting pada tanaman padi di Indonesia. Hama ini telah menimbulkan masalah serius pada tanaman padi di beberapa daerah di Indonesia, diantaranya di Aceh, Jawa Tengah, Lampung, Gorontalo dan Sulawesi Utara (Anonim, 2011, 2012a; Arifin, 2010; Aswad, 2014).

Hasil pemantauan penulis ternyata ditemukan hama Scotinophara sp. pada tanaman padi di Kabupaten Bolaang Mongondow Timur, oleh karena itu penulis tertarik mengadakan penelitian untuk mengetahui serangan dan populasi hama ini pada beberapa Kecamatan di Kabupaten Bolaang Mongondow Timur. Penelitian bertujuan untuk mengetahui serangan dan populasi hama Scotinophara sp. pada tanaman padi sawah di Kabupaten Bolaang Mongondow Timur.

\section{METODE PENELITIAN}

Penelitian menggunakan Metode Survei pada beberapa sentra penanaman padi di Kabupaten Bolaang Mongondow Timur, kemudian menetapkan 3 kecamatan sebagai lokasi penelitian dan tempat pengambilan sampel. Kriteria lokasi penelitian berdasarkan terdapatnya areal/petak sawah yang akan ditanami padi atau terdapatnya pertanaman padi yang berumur di bawah satu minggu. Survei bertujuan untuk menetapkan lokasi peneliti- an. Hasil survei ditetapkan tiga kecamatan sebagai lokasi penelitian yaitu Kecamatan Tutuyan Kecamatan Nuangan dan Kecamatan Kotabunan. Masing-masing kecamatan terdiri dari tiga petak sawah sebagai tempat pengambilan sampel.

Pengambilan sampel menggunakan Metode Irisan Diagonal dengan memilih sepuluh rumpun tanaman padi pada setiap sub-petak sampel. Pengambilan sampel dilakukan pada fase vegetatif menggunakan metode penyapuan yaitu dengan menggunakan jaring serangga yang diayunkan pada permukaan tanaman sebanyak lima kali ayunan ganda, sedangkan pengambilan sampel pada tanaman fase generatif dilakuan dengan memilih sepuluh rumpun tanaman pada masingmasing sub-petak sampel kemudian dilakukan penangkapan imago maupun nimfa menggunakan tabung reaksi besar. Sampel yang tertangkap dikoleksi di dalam botol beralkohol $70 \%$. Sampel diberi label sesuai lokasi dan waktu pengambilannya, kemudian dibawa ke Hayati Balai Perlindungan Tanaman Pangan dan Hortikultura Provinsi Sulawesi Utara. Pengambilan sampel dilakukan sebanyak dua kali pada fase vegetatif dengan umur tanaman 2-4 mst dan dua kali pada fase generatif dengan umur tanaman 6-8 mst. Penelitian dilaksanakan pada bulan Juli sampai bulan Oktober 2014.

Hal-hal yang diamati dalam penelitian ini adalah persentase tanaman terserang dan populasi Scotinophara sp.

\section{Persentase Tanaman Terserang}

Pengamatan persentase tanaman terserang dilakukan dengan menentukan 10 rumpun tanaman pada masing-masing sub-petak sampel untuk diamati. Jadi pada setiap petak terdapat 50 rumpun padi yang diamati. Kategori rumpun tanaman terserang ditandai dengan terdapat imago dan atau nimfa pada sampel tanaman. Tanaman yang terserang dicatat dan dihitung jumlahnya. Untuk menghitung persentase tanaman terserang digunakan rumus : 


$$
\text { Persentase serangan }=\frac{\text { Jumlah tanaman terserang }}{\text { Jumlah rumpun tanaman yang diamati }} \times 100 \%
$$

\section{Populasi Hama Scotinophara sp.}

Koleksi sampel yang diperoleh dari pengambilan di lapangan dihitung berdasarkan lokasi pengambilan. Untuk mengetahui rata-rata populasi hama digunakan rumus sebagai berikut :

$$
\text { Populasi }=\frac{\text { Jumlah nimfa } / \text { imago yang ditemukan }}{\text { Jumlah rumpun yang diamati }}
$$

\section{HASIL DAN PEMBAHASAN}

\section{Persentase Serangan}

Hasil pengamatan serangan pada tanaman padi yang disebabkan oleh hama kepinding tanah pada tiga kecamatan berdasarkan umur tanaman tertinggi di jumpai pada tanaman padi yang berumur 8 mst mencapai $66,66 \%$, diikuti 6 mst, yaitu 37,33, dan terrendah $4 \mathrm{mst}, 5,33 \%$ dan $2 \mathrm{mst}$, $0 \%$,seperti terlihat pada Tabel 1. Tanaman yang diserang oleh kepinding tanah terlihat berwarna kuning kecoklatan. Kepinding ini menghisap cairan tanaman yang mengakibatkan terjadinya pengurangan cairan sari makanan dari tanaman. Hal ini dapat mengurangi energi dan unsur hara yang seharusnya berguna untuk pertumbuhan dan perkembangan tanaman. Menurut Reissig, et.al. (1985) nimfa dan imago menghisap cairan tanaman pada batang sehingga mengakibatkan tanaman menjadi kerdil dengan daun-daun yang berwarna coklat kemerahan atau kuning. Serangan pada awal musim atau fase vegetatif menyebabkan pengurangan jumlah anakan dan rumpun yang menjadi kerdil. Menurut Gallagher (1991), kepinding tanah yang menyerang pada fase generatif mengakibatkan malai tidak berkembang sempurna dan bulir kosong (berwarna putih). Pada populasi yang tinggi, tanaman yang terserang hama ini dapat mati atau mengalami bugburn, dengan gejala seperti hopperburn yang diakibatkan oleh wereng coklat (Syam, et.al., 2011).

Hasil penelitian menunjukkan bahwa persentase serangan tertinggi berdasarkan umur tanaman yaitu pada fase generatif dengan umur tanaman 8 mst yakni 44,88\%, 6 mst yakni 21,48\% dan fase vegetatif dengan umur tanaman $4 \mathrm{mst}$ yakni 3,55 dan 2 mst 0 . Persentase tanaman padi terserang oleh Scotinophara sp., dari 50 tanaman sampel umur 8 minggu setelah tanam pada masing-masing kecamatan tertinggi dijumpai di Kecamatan Tutuyan yakni sebesar 66,66 persen, diikuti Kecamatan Nuangan 39,33 persen, dan Kecamatan Kotabunan 11,13 persen.

Berdasarkan data Tabel 1 terlihat bahwa lokasi Kecamatan Tutuyan, persentase tanaman padi terserang oleh Scotinophara sp. tertinggi yaitu 66,66 persen dan terendah Kecamatan Kotabunan 28,67 persen.

Dari data pada Tabel 1 memperlihatkan bahwa persentase tanaman padi terserang oleh Scotinophara sp. meningkat seiring dengan peningkatan umur tanaman. Persentase tanaman terserang berhubungan erat dengan kepadatan populasi. Hasil pengamatan populasi hama Scotinophara sp. lebih banyak ditemukan pada umur tanaman 8 mst (Tabel 2). Dilaporkan oleh Ismawati (2012) bahwa populasi kepinding tanah banyak dijumpai pada saat tanaman padi telah memasuki masa generatif, bahkan setelah panen masih ditemukan populasi kepinding tanah. Hasil penelitian Torres, et.al. (2010), populasi kepinding tanah lebih banyak ditemukan pada tanaman padi yang sudah bermalai dan masih banyak ditemukan pada jerami setelah padi dipanen.

\section{Populasi Scotinophara sp.}

Hasil penelitian menunjukkan bahwa secara umum hama Scotinophara sp. telah menyebar pada pertanaman padi di Kecamatan Tutuyan, Nuangan dan Kotabunan, Kabupaten Bolaang Mongondow Timur. Rata-rata populasi hama Scotinophara sp. pada tanaman padi sawah di Kabupaten Bolaang Mongondow Timur dapat dilihat pada Tabel 2. 
Tabel 1. Rata-rata Persentase Tanaman Padi Sawah Terserang Scotinophara sp. di Kabupaten Bolaang Mongondow Timur

(Table 1. The Average Percentage of Rice Plants Attacks by Scotinophara sp. in East Bolaang Mongondow District)

\begin{tabular}{ccccc}
\hline Umur Tanaman & \multicolumn{3}{c}{ Lokasi Sampel / Kecamatan } & \multirow{2}{*}{ Rata-rata } \\
\cline { 2 - 4 } (mgg setelah tanam) & Tutuyan & Nuangan & Kotabunan & \\
\hline 2 & 0 & 0 & 0 & 0 \\
4 & 5,33 & 4,00 & 1,33 & 3,55 \\
6 & 37,33 & 16,00 & 11,13 & 21,48 \\
8 & 66,66 & 39,33 & 28,67 & 44,88 \\
\hline
\end{tabular}

Tabel 2. Rata-rata Populasi Scotinophara sp. pada Tanaman Padi Sawah di Kabupaten Bolaang Mongondow Timur.

(Table 2. The Average Population of Scotinophara sp. to Rice Plant in East Bolaang Mongondow District)

\begin{tabular}{ccccc}
\hline Umur Tanaman & \multicolumn{3}{c}{ Lokasi Sampel / Kecamatan } & \multirow{2}{*}{ Rata-rata } \\
\cline { 2 - 4 } (mgg setelah tanam) & Tutuyan & Nuangan & Kotabunan & \\
\hline 2 & 0 & 0 & 0 & 0 \\
4 & 0,11 & 0,05 & 0,01 & 0,06 \\
6 & 10,29 & 1,55 & 1,31 & 4,38 \\
8 & 30,02 & 5,69 & 2,53 & 12,75 \\
\hline Rata-rata & 10,11 & 1,82 & 0,96 & 4,30 \\
\hline
\end{tabular}

Berdasarkan data Tabel 2, ternyata pada umur tanaman 8 minggu setelah tanam memiliki rata-rata populasi tertinggi yakni mencapai 12,75 ekor, kemudian tanaman berumur 6 minggu setelah tanam yaitu 4,38 ekor, tanaman berumur 4 minggu setelah tanaman mencapai 0,06 ekor dan pada tanaman berumur 2 minggu setelah tanaman tidak dijumpai adanya populasi hama Scotinophara sp. Hal ini menandakan bahwa migrasi hama Scotinophara sp. ke tanaman padi terjadi mulai pada saat tanaman berumur 4 mst. Perkembangan populasi Scotinophara sp. berdasarkan umur tanaman padi, fase vegetatif, 2-4 mst dan fase generatif, 6-8 mst dapat dilihat pada Gambar 1.

Dari Gambar 1 terlihat bahwa semakin bertambah umur tanaman maka semakin tinggi populasi Scotinophara sp. Puncak populasi ditemukan pada saat tanaman padi berumur 8 mst. Pada saat tanaman padi berumur 2 mst, belum ditemukan populasi Scotinophara sp. Kondisi ini berbeda dengan hasil penelitian yang dilakukan oleh
Moonik, dkk. (2015), yakni pada saat tanaman berumur 14 hst (hari setelah tanam) atau $2 \mathrm{mst}$, populasi Scotinophara sp. sudah mencapai 1,35 ekor di dataran Dumoga, Kabupaten Bolaang Mongondow. Lebih lanjut dikemukakan bahwa puncak populasi Scotinophara sp. pada tanaman padi di Kabupaten Bolaang Mongondow ditemukan pada saat tanaman berumur 42 hst, yakni rata-rata 4,15 ekor. Populasi ini lebih rendah bila dibandingkan dengan pengamatan 8 mst di Kabupaten Bolaang Mongondow Timur, yakni 12,75 ekor. Ismawati (2012) melaporkan bahwa hama kepinding tanah mulai menyerang tanaman padi saat 3 mst. Kepinding tanah yang menyerang pada 3 mst adalah fase imago. Imago ini diduga berasal dari tanaman padi di sekitarnya. Lebih lanjut dikemukakan bahwa puncak populasi Scotinophara sp. dijumpai pada saat tanaman padi berumur 9 mst, dengan rata-rata 70 ekor per 200 rumpun tanaman padi sawah. 


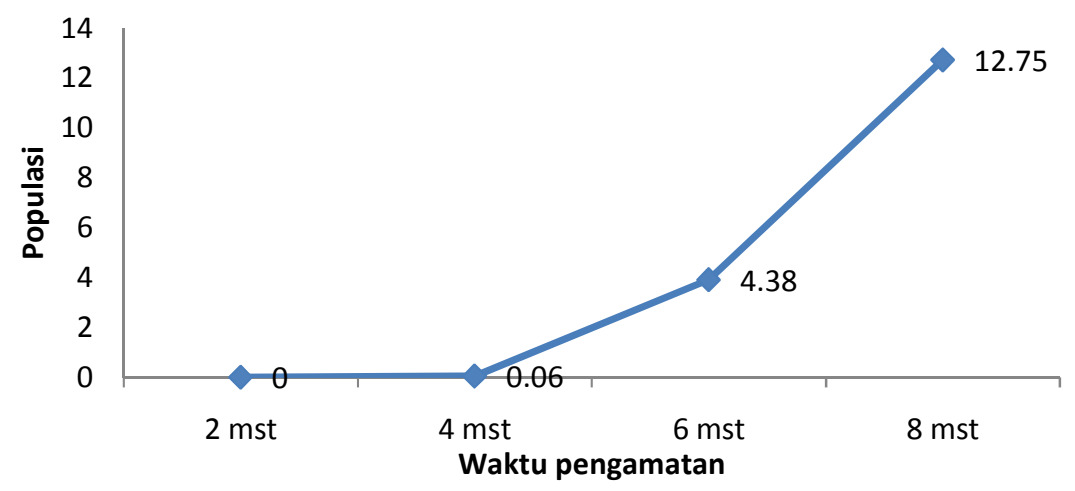

Gambar 1. Populasi Scotinophara sp. berdasarkan Umur Tanaman Padi

(Figure 1. Population of Scotinophara sp. Basedon The Age of The Rice Plant)

Tinggi rendahnya populasi hama Scotinophara sp. sangat dipengaruhi oleh beberapa faktor, salah satunya adalah faktor makanan. Terdapat kecenderungan bahwa semakin tua umur tanaman semakin disukai oleh Scotinophara sp. yang ditandai dengan populasi tertinggi pada saat tanaman padi berumur 8 mst. Makanan merupakan sumber gizi yang dipergunakan oleh serangga untuk hidup dan berkembang.

Jika ketersediaan makanan dengan kualitas yang sesuai dan kuantitas yang relatif cukup, maka populasi serangga akan naik dengan cepat (Jumar, 2000). Menurut Magsino (2009), faktor makanan sangat berpengaruh terhadap proses tumbuh dan berkembangnya hama $S$. coartata. Lebih lanjut dikemukakan bahwa hama ini lebih memerlukan karbohidrat dibandingkan protein. Karena nutrisi karbohidrat lebih banyak ditemukan pada pelepah daun dan batang tanaman padi lebih tua dibandingkan tanaman padi yang lebih muda.

Faktor iklim mikro tanaman padi diduga juga sangat mempengaruhi padatnya populasi kepinding tanah. Pada saat umur tanaman padi mencapai 8 mst populasi hama Scotinophara sp. lebih tinggi karena semakin tinggi umur tanaman semakin tanaman tersebut ternaungi sehingga berpengaruh terhadap cahaya matahari dan kelembaban tanaman tersebut. Kelembaban berpengaruh terhadap kegiatan kepinding tanah yang lebih menyukai kondisi tanah basah atau lembab untuk perkembangannya. Kepinding tanah lebih menyukai kelembaban tinggi dan terlebih lagi pada saat musim hujan (Kalshoven, 1981).

Padat populasi Scotinophara sp. pada tanaman padi sawah berdasarkan lokasi kecamatan sangat berfluktuasi. Fluktuasi populasi hama kepinding tanah di Kabupaten Bolaang Mongondow Timur dapat dilihat pada Gambar 2.

Hasil pengamatan terhadap populasi Scotinophara sp. seperti yang terlihat pada Gambar 2 , ternyata tertinggi dijumpai pada Kecamatan Tutuyan dengan rata-rata populasi mencapai 10,11 ekor, kemudian Kecamatan Nuangan 1,82 ekor dan Kecamatan Kotabunan 0,96 ekor. Tingginya populasi kepinding tanah yang ditemukan di Kecamatan Tutuyan diduga berhubungan erat dengan pola tanam dan kondisi pertanaman padi. Lokasi Kecamatan Tutuyan, areal pertanaman padi tidak seragam, ditemukan tanaman padi masa vegetatif, masa generatif, bahkan beberapa lokasi masih dalam tahap pembibitan.

Kondisi ini berbeda dengan lokasi Kecamatan Nuangan dan Kotabunan relatif kondisi pertanaman padi yang seragam, masih dalam fase vegetatif. Kondisi tanaman yang tidak seragam ini, sangat mempengaruhi fluktuasi populasi kepinding tanah. Biasanya hama kepinding tanah cenderung bermigrasi ke tanaman yang sudah memasuki fase generatif (Ismawati, 2012). Oleh karenanya populasi kepinding tanah relatif lebih banyak dijumpai di lokasi Kecamtan Tutuyan bila dibandingkan dengan lokasi lainnya. 


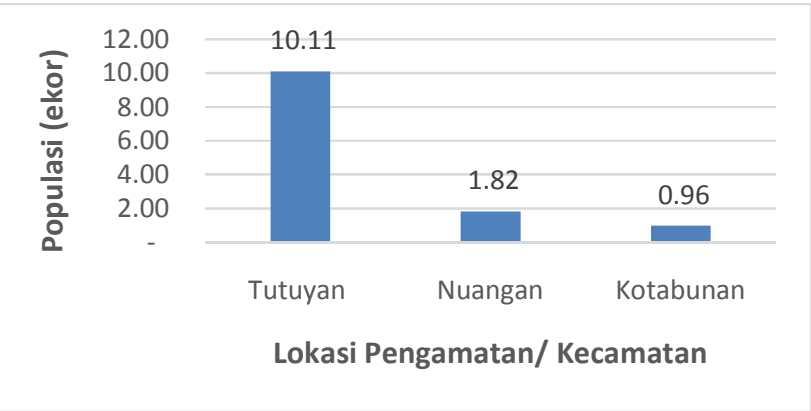

Gambar 2. Populasi Scotinophara sp. Berdasarkan Lokasi Pengamatan

(Figure 2. Population of Scotinophara sp. Based on The Observation Location)

Populasi Kepinding Tanah di Kecamatan Tutuyan, Nuangan dan Kotabunan relatif rendah dan belum perlu dilakukan pengendalian. Dilaporkan oleh Heinrichs, et.al. (1986) dalam Ismawati (2012), bahwa kerapatan populasi kepinding tanah, dengan rata-rata 6 ekor/rumpun sudah mencapai ambang ekonomi (economic threshold). Lebih lanjut dikemukakan bahwa apabila populasi telah mencapai 10 ekor/rumpun maka dapat menyebakan kehilangan hasil sampai mencapai 35 persen.

\section{KESIMPULAN DAN SARAN}

\section{Kesimpulan}

Persentase serangan tertinggi berdasarkan umur tanaman yaitu pada fase generatif dengan umur tanaman 8 mst yakni 44,88\%, 6 mst yakni $21,48 \%$ dan fase vegetatif dengan umur tanaman 4 mst yakni 3,55 dan 2 mst 0 . Persentase berdasarkan lokasi pada umur $8 \mathrm{mst}$ tertinggi di jumpai di Kecamatan Tutuyan $66,66 \%$ diikuti Kecamatan Nuangan 39,33\% dan Kecamatan Kotabunan $28,67 \%$.

Kepadatan populasi Scotinophara sp. tertinggi berdasarkan lokasi dijumpai di Kecamatan Tutuyan yakni 10,11 ekor dan terendah secara berurutan Kecamatan Nuangan dan Kecamatan Kotabunan yakni 1,82 ekor dan 0,96 ekor. Kepadatan populasi berdasarkan umur tanaman, tertinggi pada umur tanaman 8 mst yakni 12,75 ekor dan terendah secara berurutan $6 \mathrm{mst}, 4 \mathrm{mst}$ dan $2 \mathrm{mst}$ yakni 4,38 ekor, 0,06 ekor dan 0 ekor.

\section{Saran}

Perlu dilakukan pemantauan perkembangan populasi Scotinopharasp. secara berkesinambungan agar dapat dicegah kemungkinan terjadinya peledakan populasi yang dapat mengurangi produksi padi di Kabupaten Bolaang Mongondow Timur.

\section{DAFTAR PUSTAKA}

Anonim, 2011. Laporan Tahunan Dinas Pertanian dan Peternakan Provinsi Sulawesi Utara. Manado.

2012a. Mengendalikan Hama Kepinding Tanah/Ketupluk. http://www.gerbang pertanian.com/2012/12/mengendalikanhama-kepinding-tanah.html

Arifin, 2010. Hama Kepinding Tanah Pada Tanaman Padi Sawah. http://epetani. deptan.go.id/budidaya/hama-kepindingtanah-pada-tanaman-padi-sawah-760

Aswad, N. 2014. Kepinding Tanah Resahkan Warga. http://gorontalopost.com/2014/ 03/19/ kepinding-tanah-resahkan-warga/

Gallagher, K. 1991. Pengendalian Hama Terpadu untuk Padi. Jakarta: BAPPENAS. 
Heinrichs, E.A., W. Katanyukul, K.A.N.M. Rezaul, dan B.C. Misra. 1986. Management of Insect Pests in Rainfed Lowland Rice. Progress in Rainfed Lowland Rice. International Rice Research Institute. Manila. Philippines. hlm 349-358.

Ismawati. 2012. Perkembangan Populasi Kepinding Tanah Scotinophara coarctata (Fabricius) (Hemiptera: Pentatomidae) Pada Pertanaman Padi. Skripsi. Fakultas Pertanian, IPB. Bogor.

Jumar. 2000. Entomologi Pertanian. PT. Rineka Cipta Jakarta.

Kalshoven, L.G.E. 1981. The Pests of Crops in Indonesia. PT Ichtiar Baru-van Hoeve. Jakarta.

Magsino, G.L. 2009. Rice Black Bugs : The Experiences and Strategies of Laguna Farmers. SEARCA's Agriculture \& Development Seminar Series; 2009 Feb 17; Laguna. Laguna NCPC-CPC, UPLBCA (internet). (diunduh 2012 Apr 15). Tersedia pada: http://www.searca.org/ web/adss/2009/ handouts/ADSS.

Moonik. 2015. Populasi Hama Kepinding Tanah (Scotinophara coartata F.) Pada Tanaman Padi Sawah di Kecamatan Dumoga Utara Kabupaten Bolaang Mongondow.
Paendong, E., J. Pelealu dan J. Rimbing. 2011. Penyebaran Hama Kepinding Tanah dan Musuh Alaminya Pada Pertanaman Padi Sawah Di Sulawesi Utara. Jurnal IImu Pertanian Eugenia Volume 17 No. 3 Desember 2011.

Reissig, W.H., E.A. Heinrichs, J.A. Litsinger, K. Moody, Fiedler L. Mer TW. and A.T. Barrion. 1985. Illustrated Guide to Integrated Pest Management in Rice in Tropical Asia. Los Banos. Laguna. Philippines: International Rice Research Institute. hIm 147-153.

Syam, M., Suparyono, Hermanto, dan D. Wurjandari. 2011. Masalah Lapang Hama, Penyakit, Hara pada Padi. Ed ke6. Bogor: Pusat Penyuluhan Pertanian.

Torres, M.A,J., A.T. Barrion, R.C. Joshi, L.S. Sebastian, A.A. Barrion, A.L.A. Dupo, and C.G. Demayo. 2010. Systematic Relationship of Rice Black Bugs, Scotinophara spp. Inferred Using Nonmetric Multidimensional Scaling Technique and Persimony Analysis. J. Biologi Sci. 3 (1): 113-131. 